\title{
Investigation on the Electrode Process of Acetophenone by Faradaic Rectification Method.
}

\author{
by \\ Katsukiyo ITo \\ Goverment Industrial Research Institute of Nagoya, Nagoya
}

(Received June 28, 1967)

The periodic variation of electrode potential about a mean potential when the electrode is polarized by a sinusoidal current was found by Doss and Agarwal ${ }^{1)}$, and is known as rectification by electrode reaction. This rectification which is generally known as the faradaic rectification was analyzed from asymmetrical current-potential curves with respect to the equilibrium potential. Barker and his coworkers devised the method which measures the rectification voltage when the electrode is polarized by an amplitude-modulated radio frequency current. The inherently fast electrode processes were studied by this method ${ }^{2}$. Delahay and his cowokers discussed the faradaic rectification of the fast electrode processes and the electrode processes with preceding chemical reaction $^{3)}$ or with adsorption ${ }^{4)}$. Using the faradaic rectification method, Agarwal found that the transfer coefficient of quinhydron is affected by hydrogen ion $^{5}$.

In this paper the electrode process of acetophenone in acid medium was studied by the same method as was devised by Barker and his coworkers. The experimental rectification voltage of acetophenone was calculated from square wave and radio frequency polarograms ${ }^{7}$. On the othher hand, assuming that the protonization of acetophenone plays the part of preceding chemical reaction ${ }^{6}$ ) and this backwared rate is very great, a theoretical rectification voltage was derived for charge transfer reaction with preceding chemical reaction ${ }^{3)}$. The experimental rectification voltage was discussed from this theoretical rectification voltage. It is concluded that the rectification voltage of acetophenone is not affected by the hydrogen ion.

\section{Theoretical Consideration}

Relationship between the mean potential of mercury electrode and the bulk concentration of reactants-Assuming that the electrode process is represented by eqs. (1) and (2) in acid medium ${ }^{6}$, eqs. (3), (4) and (5) are introduced from Fick's differential equation.

$$
\begin{gathered}
\mathrm{C}_{6} \mathrm{H}_{5} \mathrm{COCH}_{3}+\mathrm{H}^{+} \leftrightharpoons \mathrm{C}_{6} \mathrm{H}_{5} \stackrel{+}{\mathrm{G}}(\mathrm{OH}) \mathrm{CH}_{3} \\
\mathrm{C}_{6} \mathrm{H}_{5} \stackrel{+}{\mathrm{C}}(\mathrm{OH}) \mathrm{CH}_{3}+\mathrm{e} \leftrightharpoons \mathrm{C}_{6} \mathrm{H}_{5} \dot{\mathrm{C}}(\mathrm{OH}) \mathrm{CH}_{3} \\
\partial C_{a}(x, t) / \partial t=D_{a} \partial^{2} C_{a}(x, t) / \partial x^{2}-k_{1}\left[H^{+}\right] C_{a}(x, t)+k_{2} C_{o}(x, t) \\
\partial C_{o}(x, t) / \partial t=D_{0} \partial^{2} C_{o}(x, t) / \partial x^{2}+\left[k_{1} H^{+}\right] C_{a}(x, t)-k_{2} C_{o}(x, t)
\end{gathered}
$$




$$
\partial C_{r}(x, t) / \partial t=D_{r} \partial^{2} C_{r}(x, t) / \partial x^{2}
$$

where $x$ is the distance from the electrode and $t$ the elapsed time. In eqs. (3) and (4), $k_{1}$ and $k_{2}$ are the forwad and backward rate constant of protonization (1), respectively. In eqs. (3), (4) and (5), $C_{a}(c, t), C_{o}(x . t)$ and $C_{r}(x, t)$ are the bulk concentration of acetophenone, protonized acetophenone cation and acetophenone free radical, respectively, and $D_{a}, D_{o}$ and $D_{r}$ the diffusion constant of acetophenone, protonized acetophenone cation and acetophenone free radical, respectively.

When the initial and boundary conditions are $C_{a}(x, 0)+C_{o}(x, 0)=C, C_{r}(x, 0)$ $=0, C_{o}(x, 0) / C_{r}(x, 0)=K\left(=\left[H^{+}\right] k_{1} / k_{2}\right), C_{a}(\infty, t)+C_{o}(\infty, t)=C, C_{r}(\infty, t)=0, C_{o}(\infty$, $t) / C_{r}(\infty, t)=K, \partial C_{a}(0, t) / \partial x=0, \partial C_{o}(0, t) / \partial x=-\partial C_{r}(0, t) / \partial x=$ const. $t^{-1 / 2}$, and then $\left[H^{+}\right] k_{1}+k_{2} \gg 1$ and $C_{o}(0, t) / C_{r}(0, t)=\exp \left\{n F\left(E-E_{o}\right) / R T\right\}$ where $n$ is number of electrons, $F$ the Faraday constant, $E$ the mean potential of mercury electrode, $E_{0}$ the standard potential, $R$ the gas constant and $T$ the absolute temperature, one obtains eqs. (6), (7) and (8).

where $P=\exp \left\{n F\left(E-E_{o}\right) / R T\right\}$.

$$
\begin{aligned}
& C_{a}(0, t)=C P /\{K+(1+K) P\} \\
& C_{o}(0, t)=C K P /\{K+(1+K) P\} \\
& C_{r}(0, t)=C K /\{K+(1+K) P\}
\end{aligned}
$$

The theoretical rectification voltage of acetophenone- When $k_{1} / k_{2} \ll 1$, a theoretical rectification voltage for the electrode process of eqs. (1) and (2) can be obtained for a charge transfer reaction with preceding chemical reaction ${ }^{3)}$ from the bulk concentration of eqs. (6), (7) and (8). It is expressed as $\Delta E_{\infty}$ in eq. (9).

$$
\Delta E_{\infty}=(n F / R T) V^{2}\left[\frac{2 \alpha-1}{4}+\frac{r_{s}\left\{(1-\alpha) r_{R}-r_{o}\right\}+y_{s}\left\{(1-\alpha) y_{R}-y_{R}\right\}}{2\left(r_{s}^{2}+y_{s}^{2}\right)}\right]
$$

where $V$ is the amplitude of alternating voltage, $r_{s}=r_{o}+r_{R}+r_{c t}, y_{S}=y_{o}+y_{R}, r_{o}$ $=\left(\omega^{-1 / 2}+f\right), y_{0}=\left(\omega^{-1 / 2}+g\right) / P, r_{R}=y_{R}=\omega^{-1 / 2}$ and $r_{c t}=(2 D)^{1 / 2} / k_{a} P^{1-\alpha}$. In the above eqs., $k_{a}$ is the apparent standard rate constant, $\alpha$ the transfer coefficient, $f=\left\{\left(\omega^{2}+\right.\right.$ $\left.\left.k_{2}{ }^{2}\right)^{1 / 2}+k_{2}\right\}^{1 / 2} /\left(\omega^{2}+k_{2}{ }^{2}\right)^{1 / 2}$ and $g=\left\{\left(\omega^{2}+k_{2}{ }^{2}\right)^{1 / 2}-k_{2}\right\}^{1 / 2} /\left(\omega^{2}+k_{2}{ }^{2}\right)^{1 / 2}$ where wis angular freququency. Eq. (9) does not involve the hydrogen ion concentration as parameter.

\section{Experimental}

A Yanagimoto Radio Frequency Polarograph PF-500 was used throught experiments. All the chemicals were of reagent grade. The electrolytic solutions which contained $0.1 \mathrm{~m} M$ acetophenone, $I M \mathrm{KCl}$ and $1.0 \%$ ethanol in acid medium $(\mathrm{pH}$ 2.50-4.23) were prepared.

After dissolved oxygen in the electrolytic solution was removed by bubbling nitrogen gas, direct current, square wave and radio frequency polarograms were measurred at $25 \pm 0.5^{\circ} \mathrm{C}$ in electrolytic cell with the dropping mercury electrode and the mercury pool electrode.

\section{Results}

Examination on the rate constant of the protonization by direct current polarographic method-The half wave potential was measued at pH 2.50-4.23 and the relation- 


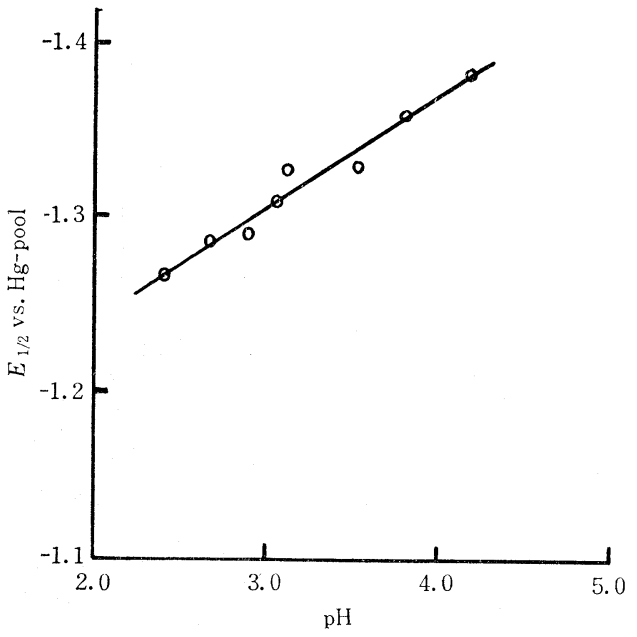

Fig. 1. Relationship between $\mathrm{pH}$ and half wave potential.

$0.1 \mathrm{~m} M$ acetophenone $+1 M \mathrm{KCl}+1.0 \%$ ethanol Temperature $; 25^{\circ} \mathrm{C}$.

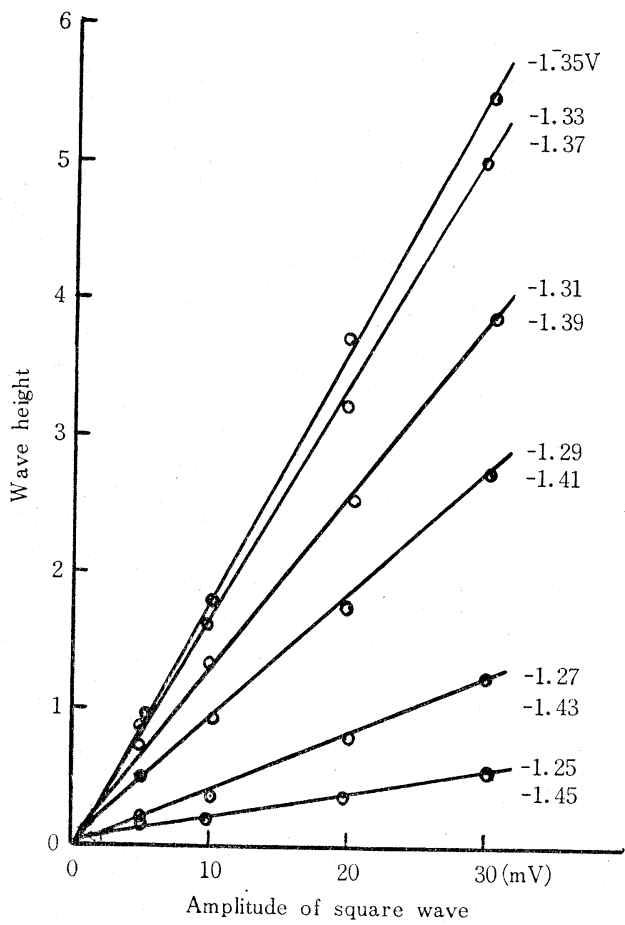

Fig. 3. Relationship between wave height and amplitude of square wave at various mean potential of mercury drop.

Parallel capacitance ; $1 \mu \mathrm{F}$. Recorder sens. : $0.2 \mu \mathrm{A} / \mathrm{mm}$. Amplifier sens. ; 1/100, Gate : 1-9, Time constant ; $1100.1 \mathrm{mM}$ acetophenone $+1 M \mathrm{KCl}+1.0 \%$ ethanol at $\mathrm{pH} 3.60$ Temperature : $25^{\circ} \mathrm{C}$.
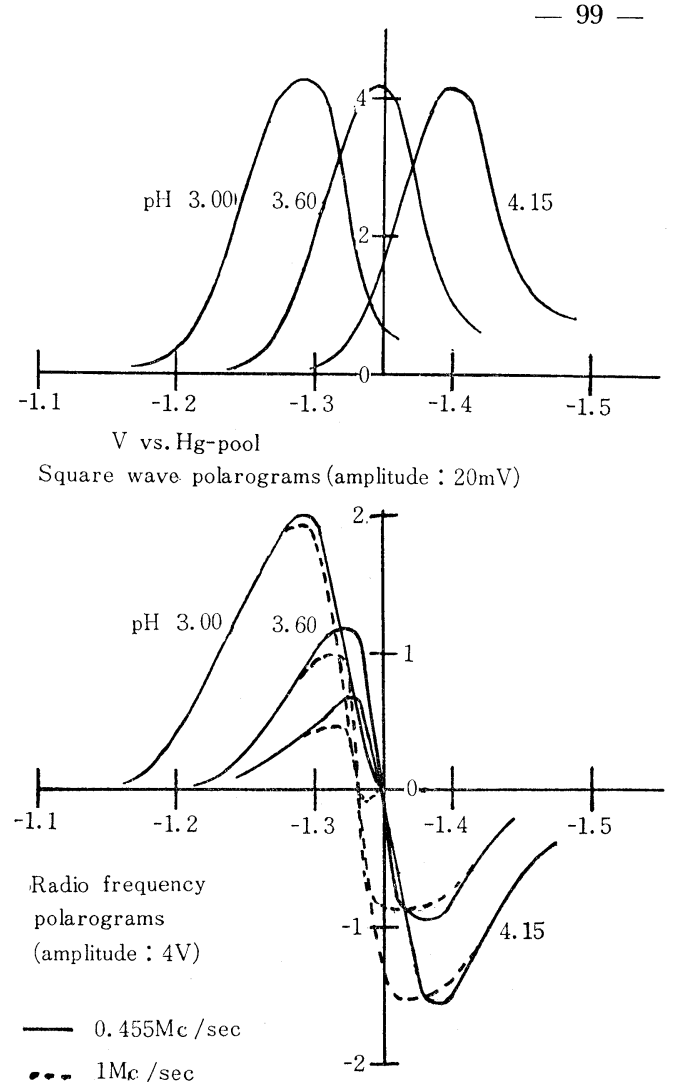

Fig. 2. Square wave and radio frequency polarograms at various $\mathrm{pH}$.

Parallel capacitance ; $1 \mu \mathrm{F}$. Recorder sens. ; $0.2 \mathrm{~A} / \mathrm{mm}$. Amplifier sens. ; $1 / 100$, Gate ; 1-9 Time constant ; 110 (without r.f. pol.) $0.1 \mathrm{~m} M$ acetophenone $+1 M \mathrm{KCl}+1.0 \%$ ethanol Temperature; $25^{\circ} \mathrm{C}$.

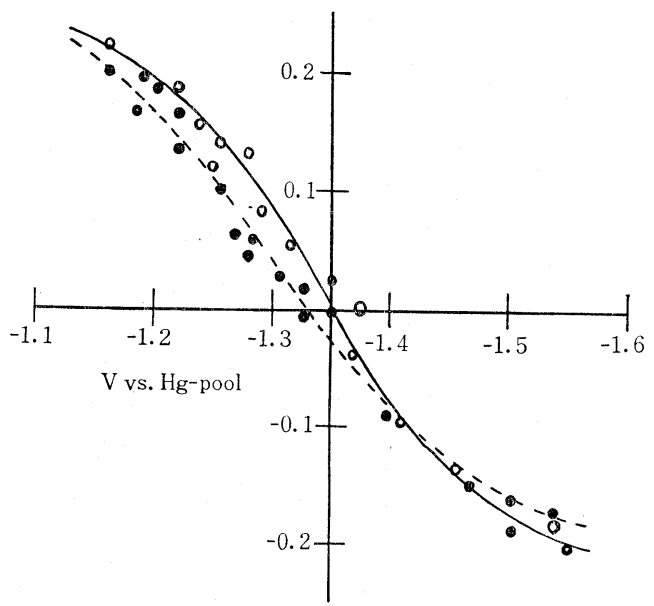

Fig. 4. The rectification voltage of acetophenone. Experimental rectification voltage : $0.1 \mathrm{~m} M$ acetophenone $+1 M \mathrm{KCl}+1.0 \%$. ethanol at $\mathrm{pH} \quad 3.00-4.15$ and at temp. $25.0^{\circ} \mathrm{C}$. $0.455 \mathrm{MC} / \mathrm{sec}, \quad 1 \mathrm{MC} / \mathrm{sec}$. Theoretical rectification voltage : $\alpha=0.4$ $\mathrm{D}^{1 / 2} / k_{a}=7 \times 10^{-3} \mathrm{sec}^{1 / 2}$ and $k_{2} \gg 10^{6} \mathrm{sec}^{-1}$. $0.455 \mathrm{MC} / \mathrm{sec},---1 \mathrm{MC} / \mathrm{sec}$. 
ship between the half wave potential and $\mathrm{pH}$ is shown in Fig.1.

Square wave and radio frequency polarograms-Square wave and radio frequency polarograms were measured at pH 3.00-4.15 and are shown in Fig.2. The wave height of the square wave and radio frequency polarogram were expressed in an arbitrary unit.

Calculation of the experimental rectification voltage ${ }^{7}$ - The wave height of square wave polarogram was meaured at the amplitude of square wave as great as $5-20 \mathrm{mV}$ and at various mean potentials of the mercury electrode. A linear relationship in Fig.3 exists between the wave height of the square wave polarogram and the amplitude of the square wave at $\mathrm{pH} 3.00-4.15$. The experimental rectification voltage of acetophenone was calculated from such a linear relationship and the wave height of the radio frequency polarogram. ${ }^{7)}$ Its value is the same at the same $\mathrm{pH}$ and at the same mean potential of the mercury electrode and a relationship is shown in Fig. 4 in an arbitrary unit.

\section{Discussion}

Examination on the rate constant of the protonization by direct current polarographic method-Eq. (10) can be derived for eqs. (1) and (2) at $25.0^{\circ} \mathrm{C}$.

$E_{1 / 2}=E_{0}+0.0591 \log \left(k_{1} / k_{2}\right)+0.0591 \log \left[H^{+}\right]-0.0591 \log \left(1+\left[H^{+}\right] k_{1} / k_{2}\right)$

where $E_{1 / 2}$ is the half wave potential. According to eq. (10), one obtains $k_{1} / k_{2} \ll 1$ from Fig. 1.

Square wave and radio frequency polarograms - The summit potential of the square wave polarogram shifts toward negative potential with increas of $\mathrm{pH}$, but the shape of square wave polarogram is independent of $\mathrm{pH}$ and radio frequency polarograms show that the positive rectification effect decreases and the negative rectification effect increases with increase of $\mathrm{pH}$ (Fig. 2). When the positive rectification effect is equal to the negative rectification effect, the mean potential of mercury electrode is independent of $\mathrm{pH}$. Its vlue is $-1.33 \mathrm{~V}$ at $1 \mathrm{MG}$ and $-1.35 \mathrm{~V}$ at $0.455 \mathrm{MG}$. This phenomenon can not be explained from Barker's discussion for single electrode process, $\mathrm{O}+n e \leftrightharpoons \mathrm{R}^{2)}$. Accordingly the other electrode process for acetophenone must be considerd.

The rectification voltage-The experimental rectification voltage is independent of the hydrogen ion concentration (Fig. 4). According to eqs. (1) and (2), when $k_{1} \ll$ $k_{2}$, the theoretical rectification voltage in eqs. (9) will not involve the hydrogen ion concentration as the parameter. It can be infered that the rectification voltage of acetophenone is equal to the theoretical rectification voltage in eqs. (9). Therefore, the electrode process of acetophenone is given by eqs. (1) and (2).

The rectification voltage of acetophenone is independent of the hydrogen ion concentration, but the square wave polarogram shifts negative potential with decrease of the hydrogen ion concentration. Accordingly the radio frequency polarogram varies with the variation of the hydrogen ion concentration (Fig. 2).

When $\Delta E_{\infty}=0$ in eq. (9), eq. (11) is derived.

$$
\begin{aligned}
& P^{2}+(2 \alpha-1) D / k_{a}^{2} P^{2}+\left\{(2 \alpha-1) \omega^{1 / 2}-(1-\alpha) \omega f\right\}(2 D)^{1 / 2} / k_{a} P^{1+\alpha} \\
& -\left\{\left(1+\omega^{1 / 2} f\right)^{2}+\left(1+\omega^{1 / 2} g\right)^{2}\right\} / 2=0
\end{aligned}
$$

According to eq. (9) and (11), the theoretical rectification voltage in Fig. 4 can be calcu- 
lated when $\alpha=0.4, D_{\frac{1 / 2}{2}} / k_{a}=7 \times 10^{-3} \sec ^{1 / 2}$ and $k_{2} \gg 10^{6} \mathrm{sec}^{-1}$.

\section{Conclusion}

From the experimental rectification voltage of acetophenone and the theoretical rectification voltage for eqs. (1) and (2), it was proved that the protonization of acetophenone plays the preceding chemical reaction.

According to eq. (9), the transfer coefficient of the electrode process of acetohenone is equal to 0.4 in acid medium.

The theoretical rectification voltage was calculated by NEG 2203. The author thanks Dr. M. Kito for this calculation.

\section{Literature}

1) K.S.G. Doss and H.P. Agarwal, J. Sci. Ind. Res., 2B, 280 (1950).

2) G.G. Barker, R.L. Faircloth and A.W. Gardner, Nature, 181, 248 (1958).

G.G. Barker, "Transaction of the Sympodium on Electrode Processes, Philadelphia, 1959," E. Yeager, Editor, John Wiley and Sons, New York, N.Y., 1961, pp. 325-365.

3) P. Delahay, M. Senda and C.H. Weis, J. Am. Chem. Soc., 83, 321 (1961).

4) M. Senda and P. Delahay, J. Phys. Chem., 65, 1580 (1961).

5) H.P. Agarwal, Bull. Chem. Soc. Japan, 37, 1393 (1964).

6) S.G. Mauanovskuu and V.N. Padov, Zhur. fiz. Khim., 38, 1804 (1964).

7) M. Senda : 11th Annual Synposium of Polarography, Sabporo (1964), Abstracts volume p. 39.

\section{ファラダイック整流作用によるアセトフェノンの電極反応に関する研究}

\section{伊藤勝清}

\section{(名古屋工業技術試験所)}

Doss と Agarwal によって発見されたファラダイ ク整流作用を利用してアセトフェノンの電極反応の解 析を試みた。装置は Barker 引によって考案された， 整流電圧を矩形波ポーラログラフ法の矩形波振幅とし て利用する方法をとる柳本高周波ポーラログラフ $\mathrm{PF}$ 509型である。

ての装置によってアセトフェノンのポーラログラム を測定すると，図 2 亿示したように，矩形波ポーラ口 グラムは $\mathrm{pH}$ の増大とともに負電位に移行するがそ の波形はほとんど変化しない。他方高周波ポーラログ ラムは $\mathrm{pH}$ の增大ととも正の整流効果が減少し負の 整流効果が増す。乙の原因は，電極反応のもっとも 単純な系 $\mathrm{O}+\mathrm{ne} \rightleftharpoons \mathrm{R}$ 亿封する Barker の報告に よると，転移系数の水素イオン濃度低存性が非常に 大きいものと考光うるが，アセトフェノンの酸性溶液 中の電極反応を単純な電極反応系として考えるにはつ ぎの二点で不可能と思われる。第 1 は周波数と高周波 ポーラログラムの関係について, pH 3.00 から $3.60 の$

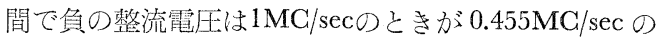
ときより大きい。第 2 は正の整流電圧と負の整流電圧 が等しくなる電位は $\mathrm{pH}$ 亿依存しない。そてで整流電
圧を矩形波ポーラログラムと高周波ポーラログラムの 波高より求省図 4 亿示す $\mathrm{pH}$ 亿依存しないもので あった。

てれらの点を説明できる系として，酸性溶液中のア セトフェノンの電極反応を Mauanovskuu らの報 告から(1)と(2)式で示されるものとした。整流電圧は 各々複極剤の電極界面濃度を Delahay らにより求 められた化学反応が先行する整流電圧の方程式にあて ほめるととにより求めた。ての時 $k_{1} / k_{2} \ll 1$ とした。て の(9)式の特徵は水素イオン濃度か湾数として含まれて いないととである。この式から $\mathrm{pH}$ 亿依存しない整流 電圧第 4 図は説明できる。また前の 2 点は $\mathrm{pH}$ 亿依存 しない整流電圧を矩形波振幅としたため, そして矩形 波ポーラログラムが $\mathrm{pH}$ の増大とともに負電位俰行 すると考光ればよい。そうすれば当然 $\mathrm{pH}$ 亿対して変 化に富んだ高周波ポーラログラムが観察されるととに なる。

以上よりアセトフェノンの電極反応は(1)と(2)式とし て考えるととができる。そてで(9)式にしたがい $\alpha=$ $0.4, D^{1 / 2} / k_{a}=7 \times 10^{-3} \mathrm{sec}^{1 / 2}, k_{x} \gg 10^{6} \mathrm{sec}^{-1}$ のとき整流電 压を計算した。この結果は図4 亿示す。 